\title{
Taxonomy for Firm-level Determinants of Export Performance
}

\author{
Pawan Kumar Chugan ${ }^{1}$, Shivangi Singh ${ }^{2, *}$ \\ ${ }^{1}$ Professor, Institute of Management, Nirma University, Ahmedabad, India \\ ${ }^{2}$ Research Scholar, Institute of Management, Nirma University, Ahmedabad, India \\ *Corresponding Author: singhamazon1209@gmail.com
}

Copyright $(0) 2014$ Horizon Research Publishing All rights reserved.

\begin{abstract}
Exporting plays a crucial role in accelerating the growth and profitability of firms. It enables them to achieve sustained competitive advantages. Interest in exporting is driven by the changing global economic scenario, liberalization, and emerging global competition. These reasons have contributed to the recent growth in research interest in the field of firm-level export performance and the major factor determining it. Existing research has certainly enhanced the understanding of firms' export performance, however, work in this field is still evolving. Given the amount of export performance research over the years, the paper presents a review of literature to highlight the key advances in this field
\end{abstract}

Keywords Exporting, Export Performance, Firm-level Export Performance, Meta-analysis

\section{Introduction}

Exporting plays a crucial role in accelerating the growth and profitability of firms thereby enabling them to achieve sustained competitive advantages. That is why there is a recent growth in research interest in the field of firm-level export performance. Existing research has certainly enhanced the understanding of firms' export performance however; work in this field is still evolving. Given the amount of the export performance research over the years several meta-analyses of literature have been produced to highlight the advances in this field e.g., Madsen [1], Aaby and Slater [2], Chetty and Hamilton [3], Leonidou and Katsikeas [4], Leonidou, Katsikeas, and Samiee [5], Zou and Stan [6], etc. These reviews have constantly shown and categorized several determinants used in the export performance research, with varied conclusions due to differences in research design, contextual factors such as the industry type on which the research focuses, country of the study, key-informant, or external environment such as socio-economic, political-legal, cultural factors, etc.

Given the fact that the literature pertaining to export performance of firms has proliferated especially in the last two decades; and a number of different methodologies have appeared, this review acquaints the readers with important trends in the field. The purpose of this paper is twofold:

(1) it provides a review of the published empirical work in this field between 1980 and 2012, and

(2) it discusses directions for future research intended to develop more encompassing research frameworks. The article begins with the methodology employed for the review, following with the elaboration of review results and then concludes with future research directions.

\section{Research Problem}

Competing in foreign markets is a complex job which needs adequate resources, knowledge and experience on the part of the firms. Firms could overcome several export market barriers by the appropriate use of resources dedicated towards international markets. The potential effect of determinants influencing export performance of the firms is an issue that deserves an in-depth study through a comprehensive review. Knowledge of determinants influencing export performance can help the firms improve their performance by various means like providing information on the market potential abroad, offering low-cost credit and providing complete knowledge of foreign markets, thereby enabling firms to adjust to those markets. The wide spread literature on export performance hence needs to be segregated on the basis of specific determinants which can act as antecedents of the firm-level export performance. The suggested study examines the issue to throw greater light on this area.

\section{Methodology}

This review focuses on the empirical literature pertaining to wide-ranging determinants of export performance. The studies included in this review follow three major criteria:

(1) the articles that are empirical in nature reporting data analysis and statistical tests. 
(2) the articles that use export performance measure(s) as the key dependent variable, and

(3) the articles which are cross-sectional in nature. Longitudinal designs and case studies are excluded.

\subsection{Identification of the Studies}

Studies included in this review were identified by a process that includes a mix of electronic means with manual investigation. The electronic search was conducted by using suitable databases. The manual search, on the other hand, was conducted by looking for the articles published in scholarly journals and the relevant books on the subject and related issues. The identified articles come from some of the most popular journals in management and international business as can be seen in references to this paper.

\subsection{Analytical Approach}

The approach used in this review is mostly based on meta-analysis technique. Classical meta-analysis requires a high degree of similarity amongst the studies reviewed with regard to the measurement of the variables and the statistical approach to data analysis [7] but as the export performance studies are categorized by a diversity of measurement and analytical approaches only a weak form of meta-analysis is applied called the 'narrative approach' involving a subjective interpretation of the overall pattern of the factors' influences on export performance (e.g., Madsen [1]; Aaby and Slater [2]).

\section{Results of the Review}

Information on the studies' characteristics in terms of country(s) of the study, size of the sample, industry type, size of the companies studied, data collection method, analytical approach(s) and the unit of analysis used are discussed in subsequent paragraphs:

\subsection{Country of the study}

The US has remained the most researched country in export performance studies for long. However, recently especially in the past decade an increased number of export performance studies were conducted in several other countries. More than half of the studies in this review involved countries other than the US. The studies covered various countries viz. UK, Germany, Finland, Greece, and Portugal from Europe; Brazil and Chile from Latin America; India, China, Bangladesh, Israel, Jordan, and Japan from Asia; Nigeria from Africa; and Australia. This is an obvious indicator that the export performance research has gained momentum and credit in all parts of the world.

\subsection{Size of the Sample}

Sample size used in the studies reviewed lies within a range of 56 to about 1000 firms. However, majority of the studies reported sample sizes in the range of 100 to 250 . Considering the number of independent variables studied and the statistical tool applied the sample size was adequate for most studies.

\subsection{Industry Type}

Majority of studies reviewed, draw sample from multiple manufacturing industry. Some studies however, focused on a single industry $[8,9,10,11,12,13]$. Singer and Czinkota [14] in their study included service firms too along with the manufacturing firms. The focus on multiple manufacturing firms can be attributed to the fact that relatively greater importance has been given to manufactured exports compared to service exports owing to the generation of higher revenues by the former. But, this trend limits the generalization of the findings to other industry contexts.

\subsection{Size of firms}

Most of the studies focused on the small and medium sized firms. It may be so because exporting by small and medium-sized firms forms the backbone of domestic economy. Also emphasis on this sector can be attributed to the facts that it leads to employment generation, reduces regional disparities of industries and promotes effective entrepreneurship, particularly in developing economies.

\subsection{Data Collection Method}

Most of the studies reviewed have used mail surveys as means for data collection. Certain studies also used personal interviews. Although mail surveys are most preferred, the use of focus groups and in-depth interviews helps to ascertain accurately the measures and determinants of firm-level export performance in an exploratory manner.

\subsection{Statistical Analysis}

While regression was widely used as an analytical approach, in many studies, the other approaches were also applied, such as the $t$ - test and chi-square test, ANOVA, discriminant analysis, factor analysis and log linear model. Another approach which has become popular more recently is the use of structural equation modeling as it enables more complex relationships to be studied simultaneously.

\subsection{Unit of Analysis}

Most of the studies used 'firm' as the unit of analysis. However, increasingly large numbers of studies used the 'export venture' as the desired unit of analysis. Cavusgil and Zou [15] and Cavusgil and Kirpalani [16] advocated that the appropriate unit of analysis in export performance research should be the export venture (a product and a market combination). Using firm as the unit of analysis for small and 
medium firms having limited product lines and markets is appropriate; but it can result in imprecise measures of performance variables with studies that target larger firms having diversified business portfolios. The appropriate level of analysis hence depends on the aim of the study. If the aim of the study concerns predicting the overall performance of the firm the appropriate level of analysis could be the 'firm-level'; while for specific product lines use of 'export venture' is worthwhile.

Table 1. Classification of the Determinants of Export Performance

\begin{tabular}{|c|c|}
\hline List of variables & Codes \\
\hline Internal (I) & \\
\hline Export Marketing Strategy(EMS) & \\
Product strategy & I-EMS-PdS \\
Pricing strategy & I-EMS-PS \\
Promotion/ Advertising strategy & I-EMS-PrS \\
Distribution channel/channel relationship & I-EMS-DC \\
Strategic decision making & I-EMS-S \\
\hline Firm Characteristics(FC) & \\
Size & I-FC-S \\
Age & I-FC-A \\
Technology innovation & I-FC-TI \\
International experience & I-FC-IE \\
Location/Access to infrastructure/services & I-FC-LIS \\
Firm resources/capabilities & I-FC-RC \\
\hline Management Characteristics(MC) & \\
Export expertise & I-MC-EE \\
Export commitment and attitude & I-MC-EC \\
Corporate social responsibility & I-MC-CSR \\
Perceived export advantages & I-MC-EA \\
Perceived export barriers & I-MC-EB \\
\hline External(E) & \\
\hline Foreign Market Characteristics(FMC) & \\
Export market barriers & E-FMC-B \\
Legal and political environment & E-FMC-LP \\
Socio-cultural environment & E-FMC-SC \\
\hline Domestic Market Characteristics(DMC) & \\
Export market barriers & E-DMC-EA \\
\hline Legal and political environment & E-DMC-DMC-LP \\
\hline
\end{tabular}

\section{The Determinants of Export Performance}

The conspicuous difficulty of the export performance studies reviewed here is the array of variables proposed by researchers that influence firm-level export performance. This review for the purpose of clarity has hence, classified the several variables determining the firm-level export performance into two broader categories building on the previous theoretical frameworks by e.g. Madsen [1]; Aaby and Slater [2]; Zou and Stan [6]. The determinants of export performance have been divided into two categories, 'Internal' and 'External' variables. Internal variables further include 'Management Characteristics and Attitudes', 'Firm Characteristics and Competencies' and 'Export Marketing Strategy' while external variables include 'Foreign Market Characteristics' and 'Domestic Market Characteristics'. Table 1 classifies the determinants with their codes as used in this study while Table 2 presents these variables as used in previous studies.

Table 2. Determinants of Export Performance of the reviewed studies

\begin{tabular}{|c|c|c|}
\hline Authors & Internal (I)* & External (E)* \\
\hline $\begin{array}{c}\text { Al-Hyari and } \\
\text { Abutayeh (2011) }\end{array}$ & & E-FMC-B \\
\hline Alvarez (2004) & $\begin{array}{l}\text { I-FC-TI, } \\
\text { I-MC-EE }\end{array}$ & E-DMC-EA \\
\hline $\begin{array}{c}\text { Axinn and Thach } \\
\text { (1990) }\end{array}$ & $\begin{array}{l}\text { I-EMS-DC, } \\
\text { I-EMS-PS, } \\
\text { I-MC-EC }\end{array}$ & \\
\hline $\begin{array}{l}\text { Ayan and Percin } \\
\text { (2005) }\end{array}$ & $\begin{array}{c}\text { I-EMS-PdS, } \\
\text { I-EMS-PS ,I-EM } \\
\text { S-PrS, } \\
\text { I-EMS-DC, } \\
\text { I-FC-A,I-MC-E } \\
\text { C } \\
\end{array}$ & $\begin{array}{c}\text { E-FMC-LP,E-FMC-SC, } \\
\text { E-DMC-LP }\end{array}$ \\
\hline $\begin{array}{c}\text { Boehe and Cruz } \\
(2010)\end{array}$ & $\begin{array}{l}\text { I-EMS-PdS, } \\
\text { I-MC-CSR }\end{array}$ & \\
\hline $\begin{array}{c}\text { Bonner and } \\
\text { Mcguinness (2007) }\end{array}$ & & E-DMC-EA \\
\hline Brouthers et al (2009) & $\begin{array}{c}\text { I-EMS-PrS,I-EM } \\
\text { S-DC, I-FC-S, } \\
\text { I-FC-TI, } \\
\text { I-MC-EE } \\
\end{array}$ & \\
\hline Cadogan et al (2012) & $\begin{array}{l}\text { I-EMS-S, } \\
\text { I-MC-EE }\end{array}$ & E-DMC-LP, E-FMC-LP \\
\hline $\begin{array}{c}\text { Carneiro, Rocha and } \\
\text { Silva (2011) }\end{array}$ & $\begin{array}{l}\text { I-MC-EE, } \\
\text { I-MC-EC }\end{array}$ & E-DMC-B \\
\hline $\begin{array}{c}\text { Cavusgil and Zou } \\
\text { (1994) }\end{array}$ & $\begin{array}{c}\text { I-EMS-PdS,I-E } \\
\text { MS-PS , I-FC-IE, } \\
\text { I-MC-EC }\end{array}$ & \\
\hline Chugan (1997) & I-FC-S, I-FC-TI & E-DMC-EA \\
\hline $\begin{array}{l}\text { Contractor, Hsu and } \\
\text { Kundu (2005) }\end{array}$ & $\begin{array}{l}\text { I-EMS-S,I-FC-S, } \\
\text { I-FC-A,I-MC-EE }\end{array}$ & \\
\hline $\begin{array}{l}\text { Diamantopoulos and } \\
\text { Schlegelmilch (1994) }\end{array}$ & $\begin{array}{c}\text { I-EMS-PdS,I-E } \\
\text { MS-DC,I-FC-IE, } \\
\text { I-FC-TI,I-MC-E } \\
\text { A, I-MC-EB } \\
\end{array}$ & E-FMC-B \\
\hline $\begin{array}{c}\text { Durmusoglu et al } \\
(2011)\end{array}$ & & E-DMC-EA \\
\hline $\begin{array}{c}\text { Francis and } \\
\text { Collins-Dodd (2004) }\end{array}$ & & E-DMC-EA \\
\hline $\begin{array}{c}\text { Freeman, Styles and } \\
\text { Lawley (2012) }\end{array}$ & I-FC-LIS & \\
\hline $\begin{array}{l}\text { Gencturk and Kotabe } \\
\text { (2001) }\end{array}$ & $\begin{array}{c}\text { I-MC-EE, } \\
\text { I-MC-EC, } \\
\text { I-FC-IE, I-FC-TI }\end{array}$ & E-DMC-EA, \\
\hline $\begin{array}{c}\text { Gertner, Gertner and } \\
\text { Guthery }(2006)\end{array}$ & $\begin{array}{c}\text { I-FC-IE, I-FC-S, } \\
\text { I-FC-A }\end{array}$ & \\
\hline Ibeh (2003) & $\begin{array}{l}\text { I-EMS-S ,I-EMS } \\
\text {-DC,I-FC-TI,I-F } \\
\text { C-IE, I-MC-EE }\end{array}$ & \\
\hline $\begin{array}{c}\text { Karelakis, Mattas, } \\
\text { Chryssochoidis } \\
\text { (2008) }\end{array}$ & $\begin{array}{l}\text { I-EMS-DC, } \\
\text { I-MC-EA }\end{array}$ & E-FMC-B,E-FMC-LP \\
\hline $\begin{array}{c}\text { Katsikeas, Piercy, } \\
\text { Ioannidis (1996) }\end{array}$ & $\begin{array}{c}\text { I-EMS-PdS,I-E } \\
\text { MS-PS ,I-EMS-P } \\
\text { rS,I-FC-S, } \\
\text { I-MC-EA }\end{array}$ & \\
\hline Koh (1991) & $\begin{array}{c}\text { I-EMS-PdS,I-E } \\
\text { MS-PS ,I-EMS-P } \\
\text { rS,I-EMS-DC } \\
\end{array}$ & \\
\hline $\begin{array}{l}\text { Lages, Lages and } \\
\text { Lages (2004) }\end{array}$ & I-EMS-DC & \\
\hline
\end{tabular}




\begin{tabular}{|c|c|c|}
\hline $\begin{array}{c}\text { Lages and } \\
\text { Montgomery (2004) }\end{array}$ & I-EMS, I-MC-EC & \\
\hline $\begin{array}{l}\text { Lages, Silva and } \\
\text { Styles (2009) }\end{array}$ & $\begin{array}{l}\text { I-FC-TI,I-EMS- } \\
\text { PdS,I-EMS-DC }\end{array}$ & \\
\hline $\begin{array}{c}\text { Lall and Kumar } \\
(1981)\end{array}$ & I-FC-TI & \\
\hline $\begin{array}{c}\text { Ling-yee and } \\
\text { Ogunmokun (2001) }\end{array}$ & $\begin{array}{l}\text { I-FC-RC, } \\
\text { I-MC-EA }\end{array}$ & \\
\hline Majumdar (1997) & I-FC-S, I-FC-A & \\
\hline Marandu (1995) & & E-DMC-EA \\
\hline $\begin{array}{c}\text { Morgan, Kaleka and } \\
\text { Katsikeas (2004) }\end{array}$ & $\begin{array}{c}\text { I-FC-RC,I-FC-IE } \\
\text {,I-EMS }\end{array}$ & \\
\hline $\begin{array}{c}\text { O'Cass and Julian } \\
\text { (2003) }\end{array}$ & $\begin{array}{l}\text { I-MC-EE,I-FC-I } \\
\text { E,I-FC-RC, } \\
\text { I-EMS-DC }\end{array}$ & E-DMC-LP \\
\hline Okpara (2009) & $\begin{array}{l}\text { I-EMS-S,I-FC-I } \\
\text { E, I-FC-RC }\end{array}$ & \\
\hline $\begin{array}{l}\text { Shamsuddoha and Ali } \\
\text { (2006) }\end{array}$ & $\begin{array}{l}\text { I-EMS-S,I-MC- } \\
\text { EC }\end{array}$ & E-DMC-EA \\
\hline Shoham (1996) & $\begin{array}{c}\text { I-EMS-PdS,I-E } \\
\text { MS-PS ,I-EMS-P } \\
\text { rS,I-EMS-DC,I- } \\
\text { EMS-S } \\
\end{array}$ & \\
\hline $\begin{array}{c}\text { Singer and Czinkota } \\
(1994)\end{array}$ & $\begin{array}{c}\text { I-FC-S,I-MC-EC } \\
\text {, I-MC-EE }\end{array}$ & E-DMC-EA \\
\hline $\begin{array}{c}\text { Singh and Chugan } \\
\text { (2013) }\end{array}$ & I-EMS-DC & \\
\hline $\begin{array}{c}\text { Sousa and Bradley } \\
(2008)\end{array}$ & I-EMS-PS & E-FMC-LP,E-FMC-SC \\
\hline Ural (2009) & I-EMS-DC & \\
\hline $\begin{array}{l}\text { Zou, Fang and Zhao } \\
\text { (2003) }\end{array}$ & $\begin{array}{c}\text { I-EMS-PdS,I-E } \\
\text { MS-PS ,I-EMS-P } \\
\text { rS,I-EMS-DC,I- } \\
\text { EMS-S,I-MC-E } \\
\text { A } \\
\end{array}$ & \\
\hline
\end{tabular}

\subsection{Internal Variables}

This category include three types of variables namely, 'Export marketing strategy', 'Firm characteristics' and 'Management characteristics'. The first type is linked with aspects of a firm's business strategy for export marketing. Commonly used strategies of marketing capabilities include product adaptation, pricing, advertising/promotion adaptation, distribution strategy/channel relationships, and strategic decision making by top executives. The second type is related to the characteristics of the firm like its size, technology innovation, international competence, location/access to infrastructure/services, and other firm resources/capabilities. The third type looks at variables related to the attitudes and perceptions of management. These include among others management's international experience, their level of export commitment and attitude towards exporting, incorporating corporate social responsibility, and perceived export advantages/barriers.

\subsubsection{Export Marketing Strategy.}

Factors related to the export marketing strategy (e.g., product, pricing, promotion, and distribution) have been profusely tested in several studies with positive implications for firm export performance in the most $[15,17,18,19,20]$.
Brouthers et al [21] in their work however, found negative association of promotion and advertising with export performance for smaller firms that concentrate in traditional, low-technology industries. Channel relationship has also exhibited positive implications for export performance $[13,22,23,24]$. Likewise, the level of strategic decision making by the top management also contribute positively to export performance $[22,25,26]$ although the magnitude of the impact is contingent on market dynamism implying that enhancing export experience and achieving export decision-making flexibility can contribute to export performance by providing access to a greater number of strategic possibilities [25].

\subsubsection{Firm Characteristics.}

Firm size has resulted in mixed effects being related positively [11]; showing negative [21] and also no association with export performance [18]. Firms' age again exhibited mixed results being positively [27], negatively[28] and not significantly related [12] to firm export performance. Technology innovation is another important determinant studied. The review asserts that most empirical studies establish a positive relationship between $R \& D$ utilization and export performance $[11,24,29]$ however, few findings reveal only a weak relationship of $R \& D$ use and export performance $[8,21]$. Firm's international competence influences its export performance is positively supported $[15,22,30]$. Firm resources and capabilities have also come out as significant determinants of export performance. Ling-yee and Ogunmokun [31] in their study looked at firm's financial resources and Supply Chain Management capabilities as positive contributors towards firm export performance. Similarly, Morgan et al [32] asserts that firm resources and capabilities affect competitive strategy and positional advantage which in turn influences the performance of export venture. A comparatively lesser researched aspect is firm's location and access to infrastructure/services. In this regard the study by Freeman et al[33] suggests that location is an important antecedent for firm resources and capabilities which in turn explains a firm's export performance.

\subsubsection{Management Characteristics.}

Management characteristics have also been correlated with export performance. Several researchers in their investigations suggest that export performance is influenced positively by the degree of export expertise the management possesses [20,25,29,30,34]. Another important variable which shows positive association with export performance is the level of commitment and attitude of the management towards exporting highlighted in the works of Axinn and Thach [9]; Cavsugil and Zou [15]; Singer and Czinkota [14]; Gencturk and Kotabe [34]; Lages and Montgomery [35]; Ayan and Percin [20] and Shamsuddoha and Ali [36] amongst others. Perceived export advantages reflects significant degree of positive association with export performance suggested by the works of Ling-yee and 
Ogunmokun [31]; Zou, Fang and Zhao [37] and Karelakis et al [13], whereas, perceived export barriers bears negative relationship with export performance shown by Diamantopoulos and Schlegelmilch [10]. One of the less researched factors in this regard is the level of corporate social responsibility undertaken by the firm's management. Boehe and Cruz [38] study contributes to the literature on corporate social responsibility and export performance by developing and empirically validating a model that explains under which conditions CSR-based product differentiation may lead to improved export performance.

\subsection{External Variables}

The previous section presented the impact of internal variables on export performance. This section will review empirical studies that have dealt with the impact of external factors on export performance. It is divided into two sub-categories of variables: 'Foreign market characteristics' and 'Domestic market characteristics'.

\subsubsection{Foreign Market Characteristics.}

The most important variable in this context is the export market barriers faced by local firms in the foreign markets. These barriers are found to impact export performance of the firms adversely [39]. Likewise, the legal-political and the socio-cultural environment prevailing in the foreign countries also have association with export performance. The sign of this relationship however differs on the basis of the type of environmental conditions. For instance Ayan and Percin [20] have found negative relationship for this variable in their study of Turkish exporters while Cadogan et al [25] and Sousa and Bradley [40] found the relationship to be positive.

\subsubsection{Domestic Market Characteristics.}

Within this category the use of export assistance has been the most prominent variable having significant positive association with export performance $[11,14,29,34,36,41,42,43,44]$. Export market barriers existing in the host country also impacts export performance negatively [45]. Legal and political environment shows mixed results with positive association with export performance in case where such an environment is conducive for exporting activities [30]. Exporters operating in more competitive environments can benefit most from engaging in exports [25].

\section{Discussion}

Considerable advancement has been made towards the empirical testing of various factors leading to superior export performance by firms. Several researchers have incorporated theoretical knowledge in developing their research models and hypotheses, which is a positive feature. Some studies $[6,10,15]$ have dwelled explicitly on developing concrete models and scales leading to strengthening of the theoretical foundations of this field. It would encourage future researchers to build upon such studies and come out with more generalized findings. This review provides us with certain new trends which could be of use to future researchers in the field of export performance: (i). the number of studies conducted outside US/UK has grown considerably incorporating less developed countries like Tanzania, Nigeria, Bangladesh, Jordan, etc. and smaller countries like Turkey, Portugal, Chile, Greece, Caribbean, Ireland, Finland, etc. This is a positive trend which should be encouraged in future research as the inclusion of different countries, particularly from the developing world will help in investigating whether our current knowledge can be generalized to these countries.

(ii).bulk of the studies focused on samples from multiple industrial sectors, similar to the observations made in earlier reviews, e.g. Zou and Stan [6]. Hence, it might be useful to focus on single and related-industry studies.

(iii).most of the studies focused on small to medium-sized firms. More studies involving large firms should be undertaken to test the validity of the conceptual models in that context too.

(iv).the use of statistical tools has gained more importance and sophistication via use of multiple regression and structural equation modeling techniques. Multivariate analysis is being conducted including the tests for mediators, moderators and control variables resulting in more encompassing research frameworks.

\section{Conclusion and Directions for Future Research}

Considerable progress has been made especially in the last two decades in formulating more evolved theory on the determinants of export performance. A positive feature is that more recent studies have incorporated some theoretical reasoning in developing their research questions and hypotheses which significantly strengthened the theoretical foundation of export performance research thereby legitimizing the academic inquiry in the field of exporting [6]. However, the field is still marked by a lack of agreement on the exact determinants of export performance which makes it a tough task to compare the findings from different studies and comes in the way of developing mature theories in the export performance literature.

The results of this review demonstrate the need for researchers to develop more elaborate conceptual frameworks and robust scales to measure the variables influencing export performance. The key points future researchers in this field should keep in mind are:

(i).there exists a need to develop frameworks and conceptualizations that include the relevant variables related to export performance literature. A right mix of external environment and internal factors must be borne in mind 
while conducting future empirical studies. In this respect, the determinants could be studied in the light of several theoretical backgrounds explaining firm performance viz. the resource-based theory, the industrial-organization theory, the structure-conduct-performance paradigm, and the theories of international trade, etc.

(ii). researchers could focus on cross-countries studies examining a group of countries at a time, to make the results more generalized in nature. A notable effort in this regard is Zou et al [46] work on developing a cross-nationally consistent conceptualization and measurement of export performance namely the EXPERF scale.

(iii). the service sector industries also needs to be dealt with while analysing export performance as they have been largely neglected till date.

(iv).the vast majority of studies reviewed involved samples drawn from multiple industrial sectors. As a result, it might be interesting for future researchers to focus on single and related-industry studies.

(v). lastly, the dearth of longitudinal studies is an inhibiting factor to dynamic model building. Future work should, therefore, consider adopting a longitudinal design which might help with the development of export marketing theory by evaluating the long-term effect of the functional relationships between export performance and its determinants.

\section{REFERENCES}

[1] T.K. Madsen. Empirical Export Performance Studies: A Review of Conceptualizations and Findings, in Cavsugil, S.T. (ed.), Advances in International Marketing, Greenwich, CT; JAI Press, 2:177-198,1987

[2] N.E. Aaby, and S.F. Slater. Management Influences on Export Performance: A Review of the Empirical Literature 1978-88. International Marketing Review, vol.6, no.4, pp. $7-25,1989$

[3] S.K. Chetty, and R.T. Hamilton. Firm-Level Determinants of Export Performance: A Meta-Analysis. International Marketing Review, vol.10, no.3, pp. 26-34,1993

[4] L.C. Leonidou, and C.S. Katsikeas. The Export Development Process: An Integrative Review of Empirical Models. Journal of International Business Studies, Vol.27, No.3, pp.517-551,1996

[5] L.C. Leonidou, C.S. Katsikeas, and S. Samiee. Marketing Strategy Determinants of Export Performance: a Meta-Analysis. Journal of Business Research, vol.55, no.1, pp. 51-67,2002

[6] S. Zou and S. Stan. The Determinants of Export Performance: A Review of the Empirical Literature between 1987 and 1997, International Marketing Review, 14(2): $107-123,1998$

[7] L.V. Hedges, and I. Olkin. Vote-counting methods in research synthesis. Psychological Bulletin, Vol. 88 No. 2, pp.
$359-69,1980$

[8] S. Lall, and R. Kumar. Firm-Level Export Performance in an inward -looking economy: The Indian Engineering Industry. World Development, Vol.9, No.5, pp.453-463,1981

[9] C.N. Axinn, and S.V. Thach. Linking export performance to the marketing practices of machine tool exporters in Cavusgil, S.T. and Axinn, C. (Eds), Advances in International Marketing, JAI Press, Greenwich, CT, Vol. 4, pp. 117-39,1990

[10] A. Diamantopoulos, and B.B. Schlegelmilch. Linking Export Manpower to Export Performance: A Canonical Regression Analysis of European and US Data, in Cavusgil, S.T., and Axinn, C. (eds.). Advances in International Marketing, JAI Press, Greenwich, CT, 6: 161-181,1994

[11] P.K. Chugan. Factors Affecting the Inter-firm Variations in Export Performance: A Case of Indian Autoparts Industry. The Indian Journal of Economics, Vol. LXXIX, No. 312: pp-45-64, July 1998,

http://papers.ssrn.com/sol3/papers.cfm?abstract id=2168044 Also see Foreign Collaboration and Export Performance: A Case of MNCs' Affiliate and Local Enterprises in Indian Automobile Industry. The Indian Journal of Economics, Vol. LXXVII, No. 306, Jan. 1997, pp. 373-390. http://ssrn.com/abstract=2164966

[12] F.J. Contractor, Hsu, C. and Kundu, S.K. Explaining Export Performance: A Comparative Study of International New Ventures in Indian and Taiwanese Software Industry. Management International Review, Vol. 45, No. 3, Aspects of the Internationalization Process in Smaller Firms , pp. $83-110,2005$

[13] C. Karelakis, Mattas, K. and Chryssochoidis, G. Greek Wine Firms: Determinants of Export Performance. Agribusiness, Vol.24,1998

[14] T.O. Singer and Czinkota, M.R. Factors associated with effective use of export assistance. Journal of International Marketing, Vol.2, No.1,1994

[15] S.T. Cavusgil and Zou, S. Marketing strategy - performance relationship: an investigation of the empirical link in export market ventures. Journal of Marketing, 58, 1-21,1994

[16] S.T. Cavusgil and Kirpalani, V.H. Introducing products into export markets: success factors. Journal of Business Research, 27, 1-15,1993

[17] A.C. Koh. Relationships among Organizational Characteristics, Marketing Strategy and Export Performance. International Marketing Review, 83(3):46-60,1991

[18] C.S. Katsikeas, Piercy, C. and Ioannidis, C. Determinants of Export Performance in a European Context. European Journal of Marketing, 30(6):6-35,1996

[19] A. Shoham. Marketing-mix standardization: determinants of export performance. Journal of Global Marketing, Vol. 10 No. 2, pp. 53-73,1996

[20] T.Y. Ayan and Percin, S. A Structural Analysis of the Determinants of Export Performance: Evidence from Turkey. Innovative Marketing, Volume 1, Issue 2,2005

[21] L.E. Brouthers, Nakos, G., Hadjimarcou, J. and Brouthers, K.D. Key Factors for Successful Export Performance for Small Firms. Journal of International Marketing, Vol.17, 
No.3, pp.21-38,2009

[22] K.I.N. Ibeh. On the internal drivers of export performance among Nigerian firms: empirical findings and implications. Management Decision, Vol. 41 Iss: 3 pp. 217-225,2003

[23] C. Lages, Lages, C.R. and Lages, L.F. The RELQUAL scale: a measure of relationship quality in export market ventures. Journal of Business Research, 58(2005) 1040-1048,2004

[24] L.F. Lages, Silva, G., and Styles, C. Relationaship Capabilities, Quality, and Innovation as Determinants of Export Performance. Journal of International Marketing, Vol. 17, No.4,2009

[25] J.W. Cadogan, Sundqvist, S., Puumalainen, K. and Salminen, R.T. Strategic flexibilities and export performance: The moderating roles of export market-oriented behavior and the export environment. European Journal of Marketing, Vol.46 Iss: 10 pp. $1418-1452,2012$

[26] J.O. Okpara. Strategic choices, export orientation and export performance of SMEs in Nigeria. Management Decision, Vol. 47 Iss: 8 pp. 1281-1299,2009

[27] R.K. Gertner, Gertner, D. and Guthery, D. The Implications of Export Performance Measurement for the Significance of the Determinants of Export Performance: An Empirical Investigation of Brazilian Firms. Journal of Global Marketing, Vol.20 (1),2006

[28] S.K. Majumdar. The Impact of Size and Age on Firm-Level Performance: Some Evidence from India. Review of Industrial Organization, 12: 231-241,1997

[29] R. E. Alvarez. Sources of export success in small- and medium-sized enterprises: The impact of public programs. International Business Review, 13(3), 383-400,2004

[30] A. O'Cass and Julian, C. Examining firm and environmental influences on export marketing mix strategy, European Journal of Marketing, 37(3/4): 366-384,2003

[31] L. Ling-yee and Ogunmokun, G.O. Effect of Export Financing Resources and Supply Chain Skills on Export Competitive Advantages: Implications for Superior Export Performance. Journal of World Business, 36(3), 260-279,2001

[32] N.A. Morgan, Kaleka, A. and Katsikeas, C.S. Antecedents of export venture performance: a theoretical model and empirical assessment. Journal of Marketing, 68, 90-108,2004

[33] J. Freeman, Styles, C. and Lawley, M. Does firm location make a difference to the export performance of SMEs? International Marketing Review, Vol.29 Iss: 1 pp. 88-113,2012

[34] E.F. Gencturk and Kotabe, M. The Effect of Export Assistance Program Usage on Export Performance: A Contingency Explanation. Journal of International Marketing, Vol.9 No.2,2001

[35] L. F. Lages and Montgomery, D. B. Export performance as an antecedent of export commitment and marketing strategy adaptation, Evidence from small and medium-sized exporters. European Journal of Marketing, Vol.38 No. 9/10, pp. 1186-1214,2004

[36] A. K. Shamsuddoha and Ali, M. Y. Mediated effects of export promotion programs on firm export performance. Asia Pacific Journal of Marketing and Logistics, 18(2), 93-110,2006

[37] S. Zou, Fang, E. and Zhao, S. The Effect of Export Marketing Capabilities on Export Performance: An investigation of Chinese Exporters. Journal of International Marketing, Vol.11, No.4, pp. 32-55,2003

[38] D.M. Boehe and Cruz, L.B. Corporate Social Responsibility, Product Differentiation Strategy and Export Performance. Journal of Business Ethics, 91:325-346,2010

[39] K. Al-Hyari and Abutayeh. Exporting Performance and Manufacturing Activities in Jordanian SMEs: External Barriers and Relationships. International Journal of Global Business, 4(1), 44-72,2011

[40] C. M. P. Sousa and Bradley, F. Antecedents of international pricing adaptation and export performance. Journal of World Business, 43 pp. 307-320,2008

[41] E. E. Marandu. Impact of export promotion on export performance: A Tanzanian study. Journal of Global Marketing, 9(1/2), 9-40,1995

[42] J. Francis and Collins-Dodd, C. Impact of export promotion programs on firm competencies, strategies and performance. International Marketing Review, 21(4), 474-495,2004

[43] K. Bonner and McGuinness, S. Assessing the impact of marketing assistance on the export performance of Northern Ireland SMEs. International Review of Applied Economics, 21(3), 361-379,2007

[44] S.S. Durmusoglu, Apfelthaler, G., Nayir, D.Z., Alvarez, R. and Mughan, T. The effect of government-designed export promotion service use on small and medium-sized enterprise goal achievement: A multi-dimensional view of export performance. Industrial Marketing Management, 41(2012), pp 680-691,2012

[45] J. Carneiro, Rocha, A. da., and Silva, J.F.da. Determinants of Export Performance: a Study of Large Brazilian Manufacturing Firms. Brazilian Administration Review, Curitiba, v.8, n.2, art.1, pp. 107-132,2011

[46] S. Zou, Taylor, C.R. and Osland, G.E. The EXPERF Scale: A Cross-National Generalized Export Performance Measure. Journal of International Marketing, Vol.6, No.3, pp.37-58,1998

[47] T. Ural. The effects of relationship quality on export performance: A classification of small and medium-sized Turkish exporting firms operating in single export-market ventures. European Journal of Marketing, Vol.43 Iss:1,2009

[48] S. Singh and Chugan, P.K. The Relationship Marketing: Effect on Firms' Export Performance (A study of small and medium sized exporters in Gujarat state of India). Changing Paradigms in Services Marketing, Eds. Ashwini K. Awasthi, Sanjay Jain and Jayesh Aagja, Himalaya Publishing House, Mumbai, pp.18-29,2013 Available at: http://papers.ssrn.com/sol3/papers.cfm?abstract_id=2212030 